\title{
IAMJ
}

INTERNATIONAL

AYURVEDIC

MEDICAL JOURNAL

\section{THE ROLE OF DIFFERENT MEDIA FOR THE URDHVA PATANA OF PARADA}

\section{$\underline{\text { Kappally Smitha }}^{1}, \underline{\text { Sangeeta Rao }}^{2}, \underline{\text { Vikram }}^{3}$}

${ }^{1}$ Post Graduate Scholar, ${ }^{2}$ Associate Professor, ${ }^{3}$ Professor and HOD

Department of Rasashastra and Bhaisajya Kalpana, Sri Sri College of Ayurvedic Science and Research, Bangalore, Karnataka, India

Corresponding Author: smitha.kappally08@gmail.com

https://doi.org/10.46607/iamj2809112021

(Published Online: November 2021)

Open Access

(C) International Ayurvedic Medical Journal, India

Article Received: 23/10//2021 - Peer Reviewed: 05/11/2021 - Accepted for Publication: 06/11/2021

\section{Check for updates}

\begin{abstract}
In our ancient literature of Rasashastra, Parada or Rasa is considered the supreme Dravya out of all Rasoparasa's, Dhatu's etc ${ }^{1}$ and described to be of divine origin. The importance of Parada is highlighted mainly for Rasachikitsa. Mercury always comes with natural impurities i.e., "Naisargika dosha", when mercury is put to trade and commercial use it is adulterated with cheaper metals like Naga and Vanga for more commercial gains. As a result, mercury in the market is often available with this kind of adulterants, which are considered as "Yougika Dosha". Consumption of impure mercury is considered highly toxic and hazardous. It can be made into medicine by adopting proper Shodhana procedures. In Rasashastra process of Shodhana is having greater importance. Hence a wide range of purification methods is described for each metal and mineral including Parada. The literary meaning of Shodhana is purification, but in Rasashastra Shodana is a Samskara which essentially improves the potency along with detoxifying the metal or mineral. In our classics, various methods have been told for Shodhana of Parada, in which Patana plays a very important role $^{2}$. All the different classical references of Urdhva Patana Samskaras are compiled and critically analysed to know their role in Shodhana of Parada. Various media told are Tamra churna, Sarja Kshara, Yava Kshara, Hingu, Panchalavana and Kaashtoaushadis such as Kumari, Nisha churna etc. An attempt is made to analyse the role of various media for the Urdhva Patana of Parada.
\end{abstract}


Keywords: Parada, Shodhana, Urdhva Patana, Mercury

\section{INTRODUCTION}

Rasashastra deals with Rasaoushadhi's i.e. the drug of metallic and mineral origin. Parada is considered the supreme Dravya and is used in most of the Rasaoushadhi's. Mercury is obtained from the earth and hence there will be every chance of impurities, toxicities and heterogeneous qualities. As per Ayurveda, the Doshas of Parada are 12 and are classified under Naisargika, Yougika and Aupadika Doshas ${ }^{3}$. Mercury is commonly adulterated with cheaper metals like Naga and Vanga for more commercial gains, which are considered as "Yougika Dosha". ${ }^{4}$

In Ayurveda, Parada is never used for medicinal purposes in its crude form. According to Yogaratnakar, consuming impure Parada causes Kusta, Agnimandya, Krimi, Chardi, Arochaka, Jaadya, Daaha and Marana, while processed mercury bestows good health, relief from all diseases and even emancipation. Thus, it must go through certain Shodhana procedures before administration. Various Shodhana procedures have been explained in our Rasashastra classics to convert mercury's inherent property of toxicity into the medicinal property. Along with Shodhana, Samskaras have been told for Parada. In Rasashastra Parada Samskara is of prime importance.

Shodhana concentrates on the removal of Doshas while Samskara aims in potentiating drugs along with the removal of impurities. Samskara is the qualitative alteration done for improvement, enhancement, modifications and for lowering bad effects. ${ }^{5}$ Shodhana can be considered as a part of Samskara but all Samskaras are not Shodhana. There is a difference in opinion regarding the number of Samskaras, most of them have been considered as eighteen in number. The eighteen special procedure of purification of Parada is called Ashtadasha Parada Samskara. ${ }^{6}$ First eight procedures will have both Vyadi Nashaka property as well as Rasayana property. The remaining ten procedures are used in Dhatu Vada i.e. technique of converting nonprecious metals into precious metals. In order to use Parada for the therapeutic purpose all Rasavaidya's must perform Ashta Samskara Kriya. Out of these eight Samskaras, Patana Samskara is mainly done for removing Naga and Vanga doshas, which forms the main adulterants used in the marketing of mercury for more commercial gains. Hence Patana Samskara is considered as one of the main procedures among the Ashta Samskara's.

\section{PATANA SAMSKARA}

The pharmaceutical process in which the mercury is triturated with specified drugs and subjected for Patana (distillation) in Urdhva, Adhah or Tiryak Patana Yantra is called Patana Samskara. Here the mercury gets rid of Naga and Vanga doshas. ${ }^{8}$

Yantra's used: Patana Yantra, Vidyadhara Yantra, Damaru Yantra

VARIOUS PROCESS INVOLVED IN PATANA SAMSKARA

\section{RATIONALE.}

Bhavana -Bhavana is an important Samskara with the help of which, not only the potency of a drug can be altered but is also capable to bring about changes in characteristics of the drug by addition of new or deletion of undesirable characteristics. Bhavana facilitates in mixing of ingredients and may account for several chemical interactions in between them. It augments the properties of medicines. During grinding, the surface area of each minute particle will have contact with Dravya. Liquid media acts as a binding agent. All Bhavana Dravyas primarily contain carbon which is considered as a best reducing agent. Organic components of liquid media convert the inorganic material into organo-metallic/ organo-mineral compounds, which are favorable to the body.

Mardana- The heat produced due to continuous friction of mortar and pestle along with uniform rising temperature would seize the impurities.

Patana- Impurities like Naga, Vanga have a high boiling point do not sublimate and remain at the bottom. Parada becomes devoid of Yougika Doshas. Even in modern science, they use a triple distillation 
procedure for refining mercury, in which the temperature of mercury is carefully raised until the impurities either evaporate or the mercury itself evaporates, leaving the impurities behind. This distillation process is performed three times, with the purity increasing each time.

All the methods of Urdhvapatana explained in various Rasagrantha's have been illustrated in the table below.

\begin{tabular}{|c|c|c|c|c|}
\hline S.L. NO & REFERENCE & INGREDIENTS & QUANTITY & TIMES \\
\hline 1 & a) Rasarnav & $\begin{array}{l}\text { Parada } \\
\text { Tamra Churna }\end{array}$ & $\begin{array}{l}1 \text { part } \\
1 \text { part }\end{array}$ & 1 time \\
\hline 2 & b) Rasa Ratna Samuchaya & $\begin{array}{l}\text { Parada } \\
\text { Tamra Churna }\end{array}$ & $\begin{array}{l}1 \text { part } \\
1 / 2 \text { part }\end{array}$ & 3 times \\
\hline 3 & $\begin{array}{l}\text { c) Ayurveda Prakash } \\
\text { d) Rasendra Chintamani } \\
\text { e) Rasa Tarangini } \\
\text { f) Rasendra saarsangraha }\end{array}$ & $\begin{array}{l}\text { Parada } \\
\text { Tamra Churna } \\
\text { Nimbu Swarasa }\end{array}$ & $\begin{array}{l}1 \text { part } \\
1 / 3 \text { part } \\
\text { Q. S }\end{array}$ & $12 \mathrm{hrs}$ \\
\hline 4 & g) Rasahridya Tantra & $\begin{array}{l}\text { Parada } \\
\text { Tamra Churna } \\
\text { Jambira Nimbu Rasa }\end{array}$ & $\begin{array}{l}1 \text { part } \\
1 / 4 \text { part } \\
\text { Q. S }\end{array}$ & 1 time \\
\hline 5 & $\begin{array}{l}\text { h) Rasa Prakash Sudhakar } \\
\text { i) Rasa Tarangini }\end{array}$ & $\begin{array}{l}\text { Sarjikshara } \\
\text { Yavakshara } \\
\text { Hinga } \\
\text { Pancha lavanas } \\
\text { Parada } \\
\text { Amla Oushadi's }\end{array}$ & $\begin{array}{l}\text { 1/8th part } \\
1 / 8 \text { th part } \\
1 / 8 \text { th part } \\
\text { 1/8th part } \\
1 \text { part } \\
\text { Q. S }\end{array}$ & $12 \mathrm{hrs}$ \\
\hline 6 & $\begin{array}{l}\text { j) Ayurveda prakash } \\
\text { k) Rasa Tarangini }\end{array}$ & $\begin{array}{l}\text { Parada } \\
\text { Tuttha } \\
\text { Swarna Makshika } \\
\text { Kumari Swarasa }\end{array}$ & $\begin{array}{l}1 \text { part } \\
1 \text { part } \\
\text { Q part } \\
\text { Q.S }\end{array}$ & 1 time \\
\hline 7 & l) Rasa Manjari & $\begin{array}{l}\text { Parada } \\
\text { Kumari Swarasa } \\
\text { Nisha Churna }\end{array}$ & $\begin{array}{l}1 \text { part } \\
\text { Q.S- } \\
1 \text { part, mardana done for } 1 \text { day }\end{array}$ & 1 time \\
\hline 8 & m) Rasa Padhati & $\begin{array}{l}\text { Parada } \\
\text { Tamra churna } \\
\text { Kakamachi, Jaya } \\
\text { Brahmi, Changeri, } \\
\text { Rakta Chitraka, } \\
\text { Ankola, Amlataas } \\
\text { Tilaparni, Kumarika } \\
\text { Manduki, Chitraka } \\
\text { Pata, Kakajanga } \\
\text { Shatavari, Bhupaatali } \\
\text { Devadali, Nirgundi } \\
\text { Vishnukranth, } \\
\text { Shankhpushpi, Adraka } \\
\text { Bhangara, Gojihva } \\
\text { Kshirakandhaka, Nili }\end{array}$ & $\begin{array}{l}3 \text { parts } \\
1 \text { part }\end{array}$ & 7 times \\
\hline 9 & n) Rasa kamadhenu & $\begin{array}{l}\text { Parada } \\
\text { Devadaru, Kakatundi } \\
\text { Jaya, Karkoti, } \\
\text { Mushali, Shrikhandam } \\
\text { Kumari }\end{array}$ & $\begin{array}{l}1 \text { part } \\
\text { Q.S } \\
\text { Mardana done for } 1 \text { day }\end{array}$ & 1 time \\
\hline
\end{tabular}


DIFFERENT MEDIA USED CAN BE BROADLY CLASSIFIED AS

- Tamra and its Compounds

- Lavana Varga

- Kshara Varga

- Amla Varga

- Kaastoushadhi’s

\section{DISCUSSION}

ROLE OF DIFFERENT MEDIA USED IN SHODHANA

The media's used in the process of Shodhana attributes a very important role by breaking down or altering the chemical constituents of the drug. Our Acharya's have suggested various techniques along with different media for the Shodhana depending on the drug and purpose. Various physicochemical changes occur depending upon the selection of the media, such as variation in the elemental composition of major elements, reduction in particle size, addition as well as deletion of minor elements from the raw material, variation in density and granular size. The liquid media used acts like a solvent to dissolve the material for easy separation from the insoluble impurities to eradicate toxic chemical substances from the drugs and leads to the physical transformation of some metals and minerals. Different liquid media are derived from different sources and possess different physical, chemical and therapeutic properties thereby may influence the nature of the final product. Sometimes liquid media act as a detoxifying agent and sometimes help to enhance the therapeutic efficacy of the drug.

\section{ROLE OF TAMRA AND ITS COMPOUNDS}

Tamra forms complex structures with Doshas present in Parada and settles down thus helping in evaporating pure Parada upwards leaving the impurities at the bottom.

Cupper due to their high efficiency in removing $\mathrm{Hg} 2+$ from aqueous solution, the use of copper shavings for the removal of mercury from contaminated water is suggested, employing a sequential system of mercury amalgamation followed by the removal of mobilized copper by an ion exchanger such as zeolites. ${ }^{9}$

\section{ROLE OF AMLA VARGA}

Amla Varga dissolves the acid-soluble impurities. Acidic drugs are rapidly absorbed from the stomach when taken orally as they remain in the acidic medium of the stomach in an unionised form which favours their absorption. The organic acids present in the Amla Varga are ascorbic acid, tartaric acid, oxalic acid, citric acid, etc. Studies have proved that these acids possess antibacterial, antifungal, antioxidant and many more properties. These organic acids purify the respective metal/mineral and introduce trace elements in them so that the product formed is completely bio-assimilable and may also introduce more brittle properties while processing so that the Bhasma of the metal/mineral forms at a faster rate. Amla Varga is a natural chelator, citric acid disaggregates mineral grains and helps in separating undesired elements like Naga and Vanga from Parada.

\section{ROLE OF KSHARA VARGA}

Kshara Varga (Sarja, Yava, Tankana) because of its teeksna guna induce shodhana and attributes to agnibhuta. It helps in the dissociation of molecules. In Rasashastra the kshara plays its role in different pharmaceutical procedures such as Shodhana, Jarana, Marana etc. Kshara Because of its alkalinity in nature helps in the corrosion of unwanted material from the desired product and because of its cleansing property, are grouped under Sodhaniya Gana and is useful in the preparation of metal extracts, etc.

Kshara is used in the Marana process especially for the Puti Louha group of metals having a low melting point, also helps in the process of Jarana.

One of the papers published on borax in experimental and toxicology pathology clearly showed that the tested boron compounds (5-20 ppm) significantly reduced the genotoxic effects induced by low doses of heavy metals. Their results revealed that the protective roles of boron compounds occurred with the effectiveness on their antioxidant capacity. ${ }^{10}$ 


\section{ROLE OF LAVANA VARGA}

Lavanas are used widely in various pharmaceutical procedures such as Shodhana of Tamra, Parada etc. In Rasalinga Nirmana Saindhava Jala is used, in the preparation of Kupipakva Rasayana such as Rasa Pushpa and in Vanga Jarana Samudra Lavana is used. Lavana helps in the purification of mercury by forming salts with their impurities. It increases the Bubukshutha of Parada, thereby helping in Jarana of Bheeja. Lavanas induce Deepana, Pachana and are Sroto Shodhaka. Lavana possesses Ushna, Teekshna and Vishada Guna which might help in eliminating Parada Doshas.

\section{ROLE OF KAASTOUSHADHI'S.}

Haridra (curcumin, turmerol, zingiberine) forms a bond with $\mathrm{Hg}$, does chemical detoxification and purification. Kumari Swarasa constitutes aloe resin A, B, $\mathrm{C}$ and Aglyconealoesone. These resinous constituents bind the ingredients and give shape and compactness. Other constituents are Hydroxyanthraquinone, barbaloin $\gamma$-hydroxyaloinisomers and emodinchrysophanol, derivatives of $\gamma$-hydroxyaloinisomers and emodinchrysophanol will aid medicinal attributes.

Kumari and Haridra act as chelating agents thereby reducing the bioavailability and GI absorption of heavy metals. Also, they fasten the excretion of toxins through faeces.

Plant products make the mineral action fast, increase the potency of Dravya, decrease toxicity and particle size. All Bhavana dravyas primarily contain carbon which is considered the best reducing agent. Organic components of liquid media are transformed into the drug \& make it organo-metallic/organo-mineral compounds, which are favourable to the body.

One of the papers published showed that plantmediated detoxification of mercury and lead. They have investigated to find an eco-friendly and recyclable technique for the removal of heavy metal contamination from natural resources. Among these plant wastes seem to be the best candidates and they are suitable for detoxification of heavy metals. ${ }^{11}$

\section{CONCLUSION}

Parada has many impurities and hence cannot be administered in its crude form. It must undergo processing before being used therapeutically. Our Acharya's have told various Shodhana and Ashtadasha Samskaras for Parada. In Rasashastra Parada Samskara is of prime importance. Out of these Ashtadasha Parada Samskara, Patana Samska$r a$ is done mainly to eradicate Naga and Vanga Doshas. The media used in the process of Shodhana has an important role in breaking down or altering the chemical constituents that are not required. Various physico-chemical changes occur depending upon the selection of media. Our Acharya's have suggested various techniques along with different media's for Shodhana, depending on the nature of the drug and purpose. Hence one can find abundant methods of Shodhana using different media and techniques in our classics of Rasashastra.

\section{REFERENCES}

1. Indradev Tripati(ed). Rasendra Sara Sangraha. Varanasi: Chaukamba Orientalia;2010. Pp.5.

2. Jaya krishnadas Ayurveda Granthamala (Ed). Rasaprakasha Sudhakara by Acharya Yashodhara; Chowkamba Orientalia; 2004. Pp.151.

3. Dattareya Ananth Kulkarni(ed). Rasa Ratna Samuchaya by Vagbhatacharya, new Delhi: Meharchand Lachhmandas publications, 2007,11th chapter, verse 20, Pp.207.

4. Dattareya Ananth Kulkarni(ed). Rasa Ratna Samuchaya by Vagbhatacharya, new Delhi: Meharchand Lachhmandas publications, 2007,11th chapter, verse 18, Pp.207.

5. Vidyadhar Shukla and Ravidhat Tripati(ed). Charaka Samhita by Agnivesha, Varanasi, Chaukhambha Sanskrit Series office, 2000.Vimana sthana $1^{\text {st }}$ chapter, verse 21. Pp.554.

6. Dattareya Ananth Kulkarni(ed). Rasa Ratna Samuchaya by Vagbhatacharya, new Delhi: Meharchand Lachhmandas publications, 2007,11th chapter, verse12-13, Pp.206.

7. Dattareya Ananth Kulkarni(ed). Rasa Ratna Samuchaya by Vagbhatacharya, new Delhi: Meharchand Lachhmandas publications, 2007,11th chapter, verse13, Pp.206. 
8. Dattareya Ananth Kulkarni(ed). Rasa Ratna Samuchaya by Vagbhatacharya, new Delhi: Meharchand Lachhmandas publications, 2007,8th chapter, verse64, Pp.156.

9. Petra Hutenloch, Karl Ernst Rohel, Kurt Czurda. Use of copper shavings to remove mercury from contaminated groundwater or wastewater by amalgamation. Environ Sci Technol.2003 Sep 15;37(18):4269-73.

10. Hasan Turkez, Fatime Geyikoglu, Abdulgani Tatar, M Sait Keles, Ibrahim Kaplan. The effects of some boron compounds against heavy metal toxicity in human blood. Experimental and toxicological pathology.2012 Jan;64(1-2):93-101

11. Brajesh Kumar, Kumari Smita, Luis Cumbal Flores. Plant mediated detoxification of mercury and lead. Arabian journal of chemistry, vol 10, supplement 2 2017 May, Pages S2335-S2342.

\section{Source of Support: Nil \\ Conflict of Interest: None Declared}

How to cite this URL: Kappally Smitha et al: The Role Of Different Media For The Urdhva Patana Of Parada. International Ayurvedic Medical Journal \{online\} 2021 \{cited November 2021\} Available from: http://www.iamj.in/posts/images/upload/2823_2828.pdf 